\title{
Boşanma ve Boşanma Sonrası Uyum: Tanımlar, Modeller ve Uyumun Değerlendirilmesi
}

\author{
Divorce and Post-divorce Adjustment: Definitions, Models and Assessment of Adjustment
}

\author{
๑ Başak Öksüzler Cabılar ${ }^{1}$, ๑ Adviye Esin Yılmaz ${ }^{1}$ \\ 1Dokuz Eylül Üniversitesi, İzmir, Türkiye
}

Boşanma, kararın alınması ve boşanma işlemlerinin sürdüğü dönemlerin yanı sıra boşanma sonrası dönemi de kapsayan stresli bir yaşam dönüşümü sürecidir. Bu süreç, yaşamın neredeyse tüm alanlarını etkilemekte ve hayat koşullarında birçok değişimi beraberinde getirmektedir. Boşanan birey, bir yandan boşanmanın gerçekliğiyle yüzleşir ve ortaya çıkan duygular ve baş edilecek değişimler olduğunu fark eder. Diğer yandan, yeni kimliğine ve yaşam tarzına doğru geçişe odaklanır. Güncel istatistikler hem dünyada hem de ülkemizde boşanma oranlarındaki artışı gözler önüne sermektedir. Dolayısıyla boşanma sürecinin uyum açısından ele alınması önemli görünmektedir. Boşanma ve boşanma sonrası uyum sürecini anlamak amacıyla ileri sürülen pek çok yaklaşım bulunmaktadır. Bu yaklaşımlar, boşanma sonrası uyumu açılama konusunda farklılaşsa da uyumu boşanma sürecinden ayırmamaktadır. Buradan hareketle, bu gözden geçirme çalışmasının çeşitli amaçları bulunmaktadır. İlk olarak güncel boşanma oranları ve boşanmanın hukuki, ekonomik, sosyal, toplumsal, psikolojik ve fizyolojik sağlık açısından sonuçlarına yer verilecektir. Ardından, boşanma ve boşanma sonrası uyumu açıklayan yaklaşımlar ve uyumun değerlendirilmesi açıklanacaktır. Boşanma ve boşanma sonrası uyumun kapsamlı bir şekilde ele alınmasının boşanan bireyin uygun bilgi ve desteğe erişimini kolaylaştıracağı düşünülmektedir. Ayrıca boşanma ve boşanmaya uyum ile ilgili sürecin doğru anlaşılması araştırmalar açısından da faydalı olacaktır.
\end{abstract}

Anahtar sözcükler: Boşanma, duygusal uyum, sosyal sorunlar

Divorce is a stressful life transformation process that includes the post-divorce stage as well as the stages of decision making and divorce proceedings. This process affects almost all areas of life and causes many changes in living conditions. On the one hand, the divorced individual confronts the reality of the divorce and realizes the intense emotions and changes to deal with. On the other hand, the individual focuses on his/her transition to a new identity and lifestyle. Current statistics reveal the increase in divorce rates both in the world and in our country. Therefore, it seems important to consider the divorce process in terms of adjustment. There are many approaches to examine divorce and post-divorce adjustment process. Although these models differ in explaining post-divorce adjustment, all of them consider adjustment as a part of the divorce process. Thus, this review study has several purposes. First of all, current divorce rates and effects of divorce in legal, economic, social terms and in terms of psychological and physiological health will be included. Then, divorce and post-divorce adjustment models and assessment of adjustment will be explained. It is believed that a comprehensive review of divorce and post-divorce adjustment would facilitate divorced individuals to access appropriate information and support. Besides, correct understanding of the process regarding divorce and divorce-adjustment will be useful for further studies.

Keywords: Divorce, emotional adjustment, social problems

\section{Giriş}

Evlilik, karşıllklı gereksinimler ve roller çerçevesinde ilerleyen ve olumlu beklentilerle kurulan bir yakın ilişki türüdür. Ancak, globalleşen dünyada meydana gelen hızlı sosyal, ekonomik ve kültürel değişimler bir dinamo etkisi yaratarak evlilik ve aile ilişkilerini etkilemiş ve bazı değişimlere yol açmıştır (Şener ve Terzioğlu 2008). $\mathrm{Bu}$ değişimlerin en dikkat çekici olanlarından biri ise boşanma oranlarıdır. Boşanma, evlilik birliğinin çeşitli nedenlere dayanarak yasal olarak sonlandırılmasıdır. Her boşanma kendine özgü yönleriyle çok boyutlu ve hem birey hem de toplum bazında etkileri olan bir deneyimdir (Canbulat 2017). Aile yapısında gerçekleşen değişimler boşanmanın doyum vermeyen bir ilişkiyi sonlandırmak için daha sık başvurulan bir yol haline gelmesine neden olmuştur.

İlgili alanyazında boşanmanın "travmatik bir yaşam krizi" ve "stresli bir süreç" gibi betimlenmesi konuya psikolojik açıdan

Yazışma Adresi/Address for Correspondence: Başak Öksüzler Cabılar, Dokuz Eylül Üniversitesi Edebiyat Fakültesi, Psikoloji Bölümü, İzmir, Türkiye 
verilmesi gereken önemin altını çizmektedir (Herman 1974, Smith Barnet 1990, Pledge 1992). Boşanma tek bir olay değil; aksine çiftleri boşanma aşamasına getiren ve boşanma kararının alındığı boşanma öncesi süreç, boşanma işlemlerinin başlatıldığı ve sürdüğ̈̈ yasal süreç ve boşanmanın yasal olarak sonuçlanmasının ardından başlayan boşanma sonrası süreç olmak üzere zamana yayılan bir yaşam krizi ve psikososyal bir yaşam geçişidir (Smith Barnet 1990, Kitson ve Holmes 1992, Pledge 1992).

Boşanma hukuki, ekonomik, sosyal, toplumsal, psikolojik ve fizyolojik olmak üzere bireyin yaşamının hemen hemen tüm alanlarında uyum sağlanması gerekliliğini doğuran pek çok değişikliğe neden olmaktadır (Herman 1974, Amato 2000). Meydana gelen eş zamanlı bu değişikliklerin yanı sıra toplumun boşanmaya ve boşanan kişilere karşı çoğu zaman damgalamaya müsait bakış açısı, boşanma sürecini diğer stresli yaşam olaylarından daha farklı bir noktaya taşımaktadır (Pledge 1992, Bevvino ve Sharkin 2003). Bu noktada boşanma sonrası uyum kavramına değinmek gerekmektedir. Boşanma sonrası uyumun nasıl tanımlandığı, hangi faktörlerden etkilendiği ve en nihayetinde nasıl ölçüleceği hem teorik hem de pratik anlamda önemli görünmektedir.

Boşanma ve boşanma sonrası uyum sürecini açılamak amacıyla çok sayıda yaklaşım ileri sürülmüştür. Bunlardan bazıları aşama odakl iken (Bohannan 1970, Kessler 1975, Wiseman 1975, Froiland ve Hozman 1977, Levy ve Joffe 1978, Ahrons 1980, Kressel 1980, Hackney ve Bernard 1990), bazıları da bir stres modelini (Hill 1958, McCubbin ve Patterson 1983, Patterson 1988) ve aile sağlamlığın (family resilience) (Patterson 2002, Walsh 2016) temel almaktadır. Uyumun değerlendirilmesinde ise, bazı araştırmalar psikolojik belirti ve sorunlar ekseninde ilerlerken (Berman 1988, Doherty ve ark. 1989, Lorenz ve ark. 1997, Kramrei ve ark. 2007, Bowen ve Jensen 2017); bazı araştırmalarda spesifik olarak boşanma sonrası uyumu hedefleyen ölçüm araçları kullanılmaktadır (Fisher 1976, 1978, Sweeper ve Halford 2006).

Bu bilgiler ışığında mevcut çalışmada gün geçtikçe artan boşanma oranları ve boşanmanın yarattığı çok boyutlu etkiler göz önünde bulundurularak, boşanma olgusuna klinik psikoloji temelli bir bakış açısı getirilmesi amaçlanmaktadır. Bu amaç doğrultusunda, öncelikle boşanmaya dair güncel istatistiklere yer verilecek ve boşanma deneyimi hukuki, ekonomik, sosyal, toplumsal, psikolojik ve fizyolojik etkileri bakımından ele alınacaktır. Ardından, boşanma sonrası uyumun nasıl tanımlandığı ve hangi faktörlerden etkilendiği incelenecek, boşanma sonrası uyumu açıklayan yaklaşımlar aktarılacaktır. Son olarak uyumun değerlendirilmesine yönelik farklı bakış açıları gözden geçirilecektir. Böylece yoğun duyguların eşlik ettiği ve psikolojik olarak zorlayıcı bir yaşam deneyimi olarak kabul edilen boşanma süreci kapsamlı bir şekilde ele alınmış olacaktır. Bu bağlamda mevcut araştırmanın, boşanmanın yol açtığı güçlüklerin doğru bir şekilde değerlendirilmesinde fikir verici olması ve boşanan bireyin içinde bulunduğu sürecin doğasına uygun müdahale programlarının geliştirilmesinde yol gösterici olması bakımından alanyazındaki boşluğu dolduracağı düşünülmektedir.

\section{Boşanmada Güncel Veriler}

İçinde bulunduğumuz yüzyılda evlenme ve boşanma oranlarında meydana gelen değişimler, aile sisteminde belirgin farkllılkların gözlemlenmesine neden olmuştur. Güncel istatistikler hem dünyada hem de ülkemizde boşanma eğilimindeki artı̧sı oldukça belirgin bir şekilde ortaya koymaktadır. Ekonomik Kalkınma ve İşbirliği Örgütü'nün verileri, belli bir yll içinde her 1000 kişi başına düşen boşanma sayısı anlamına gelen kaba boşanma oranlarının küresel boyutta son elli yılda düzenli bir artı̧s sergilediğini gözler önüne sermektedir (OECD 2019).

Amerika Birleşik Devletleri'nde 50 yaş ve üzeri yetişkinlerde boşanma oranlarında bir artı̧̧ görülse de boşanma oranlarının özellikle son 10 yıla göre bir düşüş sergilemekte olduğu dikkat çekicidir. Ancak bu durumun, birlikte yaşamanın daha fazla tercih edilir hale gelmesiyle evlenme oranlarındaki azalma ile ilgili olabileceği düşünülmektedir (Raley ve Sweeney 2020). Ülkemizdeki boşanma oranlarının ise Danimarka, Finlandiya, İsveç gibi İskandinav ülkelerine kıyasla daha düşük olsa da Avusturya, Hollanda, Macaristan, İsviçre ve Slovakya gibi diğer batı ülkeleriyle oldukça paralel seyrettiği görülmektedir (United Nations 2020). Türkiye İstatistik Kurumu'nun (TÜİK) 2019 yllına ait verileri, Türkiye'deki kaba boşanma oranının son yirmi yıla göre yaklaşık üç kat artmış olduğunu göstermektedir (TÜİK 1999, 2019). Bununla birlikte, boşanmaya dair 2020 yılı istatistikleri incelendiğinde kaba boşanma oranının \%o1,62 olduğu ve bir önceki yıla göre bir düşüş sergilediği görülmektedir. $\mathrm{Bu}$ durumun, hem son bir yllda evlenme oranlarında görülen \%10,1'lik azalmayla hem de pandemi koşullarının boşanma sürecini sekteye uğratmasıyla ilgili olabileceği düşünülmektedir. Nitekim, aylara göre boşanma oranları incelendiğinde 2020 ylının Nisan ve Mayıs aylarında pandemi kaynaklı belirgin bir azalma olduğu belirtilmektedir (TÜIKK 2020).

Güncel oranlar en düşük kaba boşanma oranının Hakkâri'de $(\% \circ 0,24)$, en yüksek oranın ise Antalya'da $(\% \circ 2,47)$ olduğuna işaret etmektedir. Boşanmaların \%35,3'ünün evliliğin ilk beş ylllı döneminde gerçekleştiği ve bunu \%20,7'lik bir oranla 6-10 yıllık evliliklerin izlediği görülmektedir. Ayrıca, boşanan çiftlerin çocuklarının velayetinin \%75,8 oranıyla anneye verildiği görülmektedir (TÜİK 2020).

\section{Boşanmanın Etkileri}

\section{Boşanmanın Hukuki Etkileri}

Adli sistemin parçası olan boşanmanın (Şen 2013), birey üzerindeki hukuki yansımalarını doğru okuyabilmek için ülkemizde boşanmanın yasal olarak nasıl bir seyir izlediğinin açılanması önemlidir.

"Belli boşanma sebeplerine ve hakim kararına dayanan boşanma sistemi” uygulanmakta olan ülkemizde, evlilik birliğinin sonlanması için kabul edilen yollardan biri boşanmadır. Yasal olarak tanınan boşanma nedenleri genel ve özel olmak üzere iki grupta sınıflandırılmış olup bu gruplardaki sebeplerden en az birinin gösterilmesi yasal olarak boşanma sürecini 
başlatabilmektedir (Şanlı Yalın 2017, Bozdağ 2019). Yasal sürecin seyrini etkileyen bir diğer konu ise boşanmanın anlaşmalı ya da çekişmeli olmasıdır. Anlaşmalı boşanma olması için evlilik birliğinin en az bir yıl sürmesinin yanında tarafların boşanma konusunda hemfikir olmaları ve boşanmaya bağlı maddi konular üzerinde anlaşmaya varmış olmaları gerekmektedir (Özcan Çelik 2015). Söz konusu şartları sağlayamayan çiftler için çekişmeli boşanma süreci söz konusudur (Şanlı Yalın 2017).

Boşanma kararının kesinleşmesi ile velayet, nafaka, tazminat, mal bölüşümü gibi boşanan kişiyi bağlayıcı birtakım kişisel ve mali sonuçlar doğmaktadır. Velayet, boşanan anne babanın çocukları reşit olana dek çocuklarıyla ilgili tüm sorumluluk ve yetkilere sahip olmasıdır. Genellikle eşlerden birine verilse de ortak veya müşterek velayet durumu da söz konusu olabilmektedir (Kiremitçi 2014). Nafakanın ise iştirak, yoksulluk ve yardım nafakası olmak üzere üç biçimi bulunmaktadır. Boşanan çiftin müşterek çocuğu olması durumunda çocukların bakım, koruma ve eğitim gibi temel ihtiyaçları velayetin kimde olduğundan bağımsız olarak iştirak nafakası ile giderilirken (Memişoğlu Bozan 2019), reşit olan ancak eğitimi devam eden çocuklar için ise yardım nafakası söz konusudur (Sonat 2013). Yoksulluk nafakası ise boşanan taraflardan birinin boşanma sebebiyle "yoksulluğa" düşecek olması ve talepte bulunacak eşin diğer eşe göre daha fazla kusurlu olmaması şartlarıyla bağlanabilen nafaka türüdür (Demirbaş 2018).

Boşanan çiftler hem velayet hem de nafaka konusunda anlaşmazlık yaşayabilmekte ve bu durum kişiler için zorlayıcı olabilmektedir. Boşanma sonrası ebeveyn ve çocuk arasındaki ilişkide farklılıklar görülmekte ve anne baba olarak boşanan çiftin değişen koşul ve ilişkilere uyum sağlamaları gerekmektedir. Velayet sahibi ebeveynin üzerindeki sorumluluk artmakta ve çocuğun diğer ebeveyn ile ilişkisinde belirgin değişiklikler meydana gelmektedir (Öngider 2013). Bir ebeveynin, diğer ebeveyne karşı çocuğunun/çocuklarının algısını olumsuz yönde bilinçli olarak şekillendirmeye çalışması anlamına gelen ebeveyn yabancılaştırma sendromu velayet ile ilgili problem alanlarından biridir ve gerek çocuk gerekse yabancılaştırılan ebeveyn açısından duygusal olarak oldukça yıpratıcıdır (Güler 2017).

Kusur kriterinin aranması ve süre kriterinin olmayışı nedeniyle boşanan kişiler için zorlayıcı bir başka yasal konu ise yoksulluk nafakasıdır. Kusur kriteri, nafaka ödemekle yükümlü olan tarafın, kusur bulmak amacıyla eski eşini takip etmesine neden olmakta ve bu durum eski eşler arasında süregiden bir çatışmaya yol açmaktadır. Yoksulluk nafakasının süresiz olması ise eski eşler arasındaki irtibatın ve bağın kopmaması, nafaka ödeyen tarafın ekonomik yükümlülügünün süresiz devam edecek olmasının yarattığı huzursuzluk, nafaka ödemesi alan tarafın üretim gücüne katılmaması ya da güvencesiz çalışması gibi sebeplerle hem nafaka alan hem de nafaka ödeyen taraflar açısından zorlayıcı olabilmektedir (Demirbaş 2018).

\section{Boşanmanın Ekonomik, Sosyal ve Toplumsal Etkileri}

Yaşam standartlarında bir dizi değişime yol açan boşanma, boşanan kişi için gerek ekonomik gerekse sosyal ve toplumsal açıdan uyum bozucu olabilmektedir. Boşanan birey yalnızca boşanma sürecinin yarattığı ekonomik problemler ile başa çıkmaya çalışmakla kalmamakta, aynı zamanda toplumun ve yakın çevresinin kendisiyle etkileşiminde meydana gelen değişimi de deneyimlemektedir. Bu zorlukların çocuk söz konusu olduğunda daha da şiddetli olabileceği belirtilmektedir (Amato ve Keith 1991).

Boşanma nedeniyle ekonomik kaynakların azalması, konut bulma sıkıntısı ve yapılan harcamalar kişi için uyum bozucu olabilmekte (Asanjarani ve ark. 2017) ve bu durum özellikle maddi güvencesi olmayan kişiler için daha zorlayıcı hale gelmektedir. Belli bir gelire sahip olmanın boşanma sürecini henüz karar alma aşamasında etkilediği bilinmektedir (Can ve Aksu 2016). Evlilik devam ederken çeşitli sebeplerle çalışma hayatına katılmayarak eşlerinin sağladığı gelirle geçimini sürdüren kadınlar boşanma sonrasında çalışma hayatına yönelmektedir. Ancak deneyim eksikliği, ilerlemiş yaş gibi nedenlerle bu durum pek kolay olmamaktadır. Aynı zamanda nafaka konusunda eski eşle problem yaşanması da kadınların ekonomik sıkıntılarının artmasına yol açmaktadır (Arıkan 1996). Erkekler açısından ise nafaka miktarının ve nafakayı ödeme biçiminin kişinin ekonomik gücünü aşması durumunun zorlayıcı olabileceği belirtilmektedir. Velayet hakkı kendisine verilen ebeveynin nafaka ödemelerinde yaşayacağı düzensizlik mağduriyet düzeyini artırmaktadır. Çocuğunun velayeti kendisinde olan ebeveynin geçinmek için para kazanmak zorunda olması ve bu sebeple çocuğa ayrılan vaktin yeterli olmaması, çocukların gelirle doğru orantılı kurs, hobi vb. imkanlardan mahrum kalması gibi sonuçlara zemin hazırlayabilmektedir (Amato ve Keith 1991).

Evlilik ilişkisinin sonlanması, sosyal ağın ve etkileşimin daralmasına da yol açabilmektedir. Özellikle ortak arkadaşlar ve eski eşin ailesiyle kurulan bağlarda boşanmanın yarattığı belirsizlik ile birlikte ilişkiler azalmaktadır (Kramrei ve ark. 2007). Dahası, boşanma oranlarında gözlenen belirgin artışa rağmen özellikle geleneksel toplumlarda boşanmaya ve boşanan kişilere yönelik önyargılar varlığını sürdürmektedir. Bu önyargılar ise boşanan bireyin üzerindeki baskıyı artırarak süreci daha zorlu bir hale getirmektedir (Herman 1974, Arıkan 1996). Nitekim, boşanmasına yönelik çevresinden alacağı tepkiler ve reddedilme kaygısı nedeniyle boşanan bireyin sosyal hayatı ciddi bir biçimde etkilenebilmektedir (Thomas ve Ryan 2008). Boşanma süreci ve sonrasını kadınların bakış açısından ele alan Can ve Aksu (2016), çocuklarının geleceği ve barınmanın yanı sıra kadınların en çok toplumun bakış açısı ve baskısı, boşanma gerekçesini açıklama gerekliliği, karşı cins tarafından rahatsız edilme ihtimali, geliri olmayan kadınların aile evine dönmek durumunda kalması ve kişilerarası ilişkilerde güven duygusunun kaybolması konularında endişe duyduklarını belirlemişlerdir. Benzer şekilde, boşanma deneyimi kişinin yeni bir ilişkiye yönelik bakış açısını olumsuz etkileyebilmekte, güven ve yakınlık hissetme konusunda güçlük yaşamasına sebep olabilmektedir (Karadeniz Özbek 2019).

Boşandıktan sonra genellikle anneye verilen velayet nedeniyle çocuklarından uzak kalan erkekler ise bir yandan da çevredeki insanların boşanmanın sorumlusu ve kusurlu taraf olarak 
erkeği görmeleri nedeniyle toplumun önyargılarıla mücadele etmektedirler (Arıkan 1996). Toplum tarafından boşanmanın kadınlar ve erkekler açısından benzer şekilde "başarısızlık" olarak nitelendirilmesi, boşanan kişilerin damgalanmasına yol açarak yeni ilişkilerin kurulmasını da etkilemektedir. Öyle ki, boşanan bazı kişiler boşandıklarını belli etmemeye uğraşarak yaşamaya çalıştıklarını ifade etmektedirler (Herman 1974, Arıkan 1996).

\section{Boşanmanın Psikolojik ve Fizyolojik Etkileri}

İlgili alanyazın incelendiğinde, boşanmanın "travma" (Herman, 1974), “yas” (Yárnoz-Yaben 2017), “yaşam krizi” (Wiseman 1975) “yaşam stresörü” olarak (Pledge 1992, Mastekaasa 1997) tanımlandığı dikkat çekmektedir. Bu tanımlamalara ihtiyaç duyulmasının nedeni, boşanma dolayısıyla gerçekleşen bir dizi değişiklikle beraber boşanmanın yarattığı psikolojik etkilerdir.

Yarattığı psikolojik etkiler nedeniyle boşanmanın, eşin ölüm yoluyla kaybına benzer bir deneyim olduğu düşünülmektedir (Gove ve Shin 1989). Kimi yazarlar ise boşanmayı evlilik ilişkisinin “ölümü”ne benzetmektedir. $\mathrm{Bu}$ metaforda, tıpkı bir yakının ölümünde olduğu gibi, ilişkinin kaybı ile birlikte geride yas tutanlar (boşanan çift ve varsa çocuklar) ve kayıpla ilgili işlemlerin yürümesi için ihtiyaç duyulan resmi kanallar bulunmaktadır (Alpaslan 2018). Nitekim Holmes ve Rahe (1967) boşanmanın, eşin ölüm yoluyla kaybından sonra gelen en stresli yaşam olayı olarak bildirildiğini ortaya koymuştur.

Boşanma, evlilik ilişkisinin niteliğinden ve kişinin boşanma kararındaki etkisinden bağımsız olarak yoğun duyguların yaşandığı bir deneyimdir (Yárnoz ve ark. 2008). Boşanma sonrasında başarısızlık hissinin (Peters ve Liefbroer 1997) yanı sıra acı, korku, kıskançlık, şüphe, yas (Emery 1994, Canham ve ark. 2014), üzüntü, suçluluk, utanç, yalnızlık ve öfke duygularının (Bloom ve ark. 1985, Wallerstein 1986, Emery ve Wyer 1987) olduğu duygusal bir karmaşa görülebilmektedir. Azalan benlik saygısı ve özgüven ile birlikte geleceğe yönelik artan karamsarlık duyguları da deneyimlenebilmektedir (Frisby ve ark. 2012). Bununla birlikte boşanan bireylerin, evli olanlara kıyasla daha düşük düzeyde psikolojik iyi oluş (Gove ve Shin 1989, Amato 2000, Forste ve Heaton 2004, Afifi ve ark. 2006), daha yüksek düzeyde depresyon ve anksiyete (Menaghan ve Lieberman 1986, Emery ve Wyer 1987, Doherty ve ark. 1989, Lorenz ve ark. 1997, Hope ve ark. 1999, Thuen 2001) ve alkol/sigara kullanımı (Lillard ve Waite 1995) bildirmesi ve intihar için daha fazla risk taşımaları (Trovato 1986) boşanmanın psikolojik sağlık üzerindeki farklı etkilerini gözler önüne sermektedir.

Çok sayıda araştırma boşanmanın fizyolojik sağlık açısından olumsuz etkiler yarattığını ortaya koymuştur. Evliliğin sona ermesiyle genel işlevsellikte bozulmalar görülebilmektedir (Frisby ve ark. 2012). Boşanan kişilerin evli veya bekar olanlarla karşılaştırıldıklarında daha fazla kan basıncı ve uyku problemleri bildirdikleri, kendi sağlıklarını daha olumsuz değerlendirdikleri ve daha yüksek ölüm oranlarına sahip oldukları görülmüştür (Zick ve Smith 1991, Lillard ve Waite 1995, Hemström 1996, Rogers 1996, Joung ve ark. 1997, Murphy ve ark. 1997, Sbarra ve ark. 2011).

\section{Boşanma Sonrası Uyum ve Uyumu Etkileyen Faktörler}

Boşanmanın yarattığı farklı etkiler ve boşanma sonrasında kişinin yaşamında ortaya çıkan çok sayıda değişim, boşanma sonrası uyum kavramının önemine dikkat çekmektedir. Bu bağlamda kimi araştırmacılar tarafından uyumun depresyon ve anksiyete gibi birtakım psikolojik belirtiler ve yalnızlık, başarısızlık, reddedilme gibi çeşitli duygular ekseninde tanımlandığı görülmektedir. Ancak boşanmaya uyum, bu tür olumsuz belirtilerin olmamasından daha fazlasını ifade etmektedir (Kramrei ve ark. 2007). Çünkü boşanma ekonomik, sosyal ve eski eşle ilişki gibi kendine özgü çeşitli stres faktörleri içermektedir (Sweeper ve Halford 2006).

Boşanma sonrası uyum, krizin yarattığı karışıklıktan kurtularak yeniden bir düzenin oluşturulduğu inişli çıkışlı bir süreçtir (Hill 1958). Günlük hayatın gerekliliklerini yerine getirebilmeye ve benliğin eski eşten ayrışarak yeniden şekillenmesine işaret etmektedir (Kitson ve Morgan 1990, Diedrick 1991). Bevvino ve Sharkin (2003) boşanma sonrası uyumu, boşanma deneyimini anlamlandırma olarak kavramsallaştırmaktadır. Bu bağlamda uyum, boşanmanın yarattığı bir dizi değişikliğe alışırken, psikolojik ve duygusal dalgalanmaların sona ermeye başladığı bir sürece karşılık gelmektedir (Kramrei ve ark. 2007). Kişi uyum sürecinde bir taraftan boşanmanın yarattığı psikolojik etkilerle mücadele ederken, diğer taraftan eski eşi olmadan kuracağ 1 yeni hayatında gerekli olan şeyleri düzenlemeye çalışmaktadır (Kitson ve Raschke 1981, Sakraida 2008). Aile ilişkileri yeniden tanımlandığı için boşanmaya uyum aynı zamanda bir yeni tanımlar oluşturma sürecidir. Benliğin ve ailenin hem aile içi hem de aile dışı ilişkiler nezdinde yeniden şekillendirilmesi boşanmaya uyum sürecinde gereklidir (Pais ve White 1979). Boşanan kişinin evlilik, boşanma ve benliği hakkında farklı bakış açıları geliştirdiği bu süreçte, sahip olduğu kaynaklarını kullanması da boşanmaya uyumun bir parçasıdır (Pietsch 2002). Başka bir deyişle, boşanma sonrası uyum kimlik ve rol değişiminin düzenlendiği, ailenin ve ebeveynliğin yeni gerçekliğe göre organize edildiği, eski eş ile ilişkilerin değiştiği, sosyal ve ekonomik olarak yeni bir yaşam tarzının kurulduğu duygusal ve bilişsel olarak yeniden yapılanma sürecidir (Boon 2005).

Cinsiyet, yaş, eğitim düzeyi, ilişki durumu gibi sosyodemografik bazı değişkenler ile biten evliliğe ve boşanmaya ilişkin bazı özellikler boşanma sonrası uyumu farklı şekillerde etkileyebilmektedir. Cinsiyet ve yaş konusunda farklı bulgular dikkat çekmektedir. Bazı araştırmalar erkeklerin (Diedrick 1991, Amato 2000), bazı araştırmalar kadınların (Thuen 2001) boşanma sonrası daha düşük düzeyde uyum sergilediklerini gösterirken; bazı araştırmalar da kadınlar ve erkekler arasında boşanma sonrası uyum düzeyi açısından anlamlı bir farklılık olmadığını ortaya koymaktadır (Colburn ve ark. 1992, Hensley 1996, Vukalovich ve Caltabiano 2008). Araştırmaların çoğu yaş ilerledikçe boşanma sonrası uyum düzeyinin azaldığını gösterse de (Uhlenberg ve Myers 1981, Chiriboga 1982, Wallerstein 1986, Tschann ve ark. 1989, Cooney ve Uhlenberg 1990, Veevers 1991), sınırlı sayıda araştırmada boşanmanın daha genç kişiler için daha uyum bozucu olduğu da gösterilmektedir (Gove 
ve Shin 1989). Daha yüksek eğitim düzeyi ve ilişkinin niteliğine bakılmaksızın boşanma sonrası yeni bir ilişkiye sahip olma da boşanma sonrası uyumu arttırıyor görünmektedir (Veevers 1991, Symoens ve ark. 2014).

Boşanmadan itibaren geçen zaman, boşanma kararı üzerinde algılanan etki, biten evlilik ilişkisinin niteliği, çocuk sahibi olup olmama, evlilik ve boşanmaya dair değerlendirmeler gibi boşanma ve evlilikle ilgili faktörler boşanma sonrası uyumla bağlantılı diğer bazı özelliklerdir. Boşanma üzerinden daha fazla zaman geçmiş olması, boşanma kararında daha belirleyici olmak ve biten evliliği daha problemli değerlendirmek uyum ile pozitif yönde ilişkili görünmektedir (Veevers 1991, Bevvino ve Sharkin 2003, Kalmijn ve Monden 2006, Amato ve ark. 2007). Her ne kadar tutarlı bulgular olmasa da boşanan çiftin çocuk sahibi olmasının gerek eski eşler arasındaki sınır belirsizliklerini artırması gerekse çocuğun bakımıyla ilgili sorumluluklar nedeniyle uyumu zorlaştırıcı bir etkisi var gibi görünmektedir (Veevers 1991, Madden-Derdich ve ark. 1999, Thuen 2001). Bireyin evliliğe ve boşanmaya yönelik yerleşik inançları ve tutumları da boşanma sonrası uyum üzerinde doğrudan etkilidir (Wang ve Amato 2000, Munoz-Eguileta 2007, Sayan Karahan 2021). Buna göre daha katı tutumları olan kişilerin daha fazla psikolojik sıkıntı yaşadıkları (Booth ve Amato 1991, Veevers 1991) görülmüştür.

Çoğu stresli yaşam olayında olduğu gibi psikolojik faktörler de boşanma sonrası uyum üzerinde etkili görünmektedir. Sosyal destek (Kramrei ve ark. 2007, Kołodziej-Zaleska ve PrzybyłaBasista 2016), kişinin kendini ve boşandığı eşini affedebilme kapasitesi ve öfke düzeyi (Rohde-Brown ve Rudestam 2011), algilanan stres ve baş etme stili (Sakraida 2008, Kulik ve HeineCohen 2011), kontrol odağı (Fogas ve ark. 1992) ve duygusal tutarlılık/bütünlük duygusunun (sense of coherence) (Cohen ve Dekel 2000, Kulik ve Heine-Cohen 2011) boşanma sonrası uyum ile ilişkili olduğu belirtilmektedir. Boşanmaya ilişkin suçluluk duygusu hem eski eşten ayrışma ve yakın ilişkilerin yeniden şekillenmesinde (Pais ve White 1979) hem de yeni bir duygusal ilişki kurma ve anneliğe dair işlevsellikte güçlüklere (Baum 2007) neden olarak boşanma sonrası uyumu olumsuz bir şekilde etkilemektedir. Boşanma sonrası alınan profesyonel destek, benliğe dair olumsuz duygu ve düşüncelerin yeniden değerlendirilmesini sağlayarak uyum düzeyi üzerinde etkili olmaktadır (Asanjarani ve ark. 2017).

\section{Boşanma Sonrası Uyumu Açıklayan Yaklaşımlar}

Boşanma, genel hatlarıyla karar aşamasından başlayarak dava süreci ve boşanma sonrası dönemi kapsayan uzun bir süreçtir. Boşanmanın tek bir olaydan ziyade uzun vadeli bir sürece yayıldığı görüşünden hareketle bu süreci anlamaya yönelik aşama odaklı çeşitli yaklaşımlar ileri sürülmüştür.

Bohannan'a (1970) göre boşanma, “duygusal”, "hukuki”, "ekonomik", "ebeveynsel”, "sosyal” ve "ruhsal (psychic)" olmak üzere sırası ve yoğunluğu değişebilen altı aşamada gerçekleşmektedir. Çiftin evliliklerinde bir sorun olduğunu görmezden gelmesiyle ilk aşama uzun ylllar sürebilmekte ve devam eden süreçteki yaklaşımlarına göre evlilik devam etmekte ya da bitmektedir.
Boşanmanın yasal aşamasında hem yoğun duygular hem de yasal konuların yarattığı kafa karışıklığı görülebilmektedir. Boşanmanın ekonomik ve ortak ebeveynlikle ilgili aşamalarında nafaka ve velayet gibi konular söz konusudur. Boşanan bireyin yeni bir sosyal ağ oluşturma gayreti ile ilerleyen sosyal aşamada hayatın beklenilenden farklı bir yola saptığının farkındalığı ve aynı zamanda kimliğin yeniden inşası görülmektedir. Son aşamada ise hayattaki öncelik ve değerlerin gözden geçirildiği ve kendi kendini yönetebilme yetisinin geliştiği görülmektedir (aktaran Salts 1979). Bu modelde uyum süreci ikinci aşama olan hukuki boşanmadan itibaren başlamaktadır (Hackney ve Bernard 1990).

Pais ve White (1979) boşanma sonrası uyumu "ailenin yeniden tanımlanması” süreci olarak ele almışlardır. Bu süreç, Bohannan'ın (1970) öne sürdügü altı adımlı boşanma sürecinden hareketle duygusal yeniden tanımlama, ortak ebeveynliğin yeniden tanimlanmast, yasal, ekonomik, toplumsal ve ruhsal (psychic) yeniden tanımlamadan oluşmaktadır. Duygusal yeniden tanımlama, evliliğin doğasında olan biri tarafından "seçilmiş" olmanın tersine döndügünün fark edilmesiyle kaybın arkasından tutulan yas sürecidir. Ortak ebeveynliğin yeniden tanımlanması, çocuklarla ilgili görev ve sorumlulukların yeniden şekillendiği bir süreçken, yasal yeniden tanımlama ile boşanmayla ilgili tüm yasal işlemler yürütülmektedir. Eşlerin ekonomik olarak ayrışarak bağımsız hale gelmesiyle ise ekonomik yeniden tanımlama süreci başlamış olur. Toplumsal yeniden tanımlama, evliliğini sonlandıran çiftin bireysel olarak kimliğini oluşturduğu ve bu aşamada sosyal ağlardan faydalandığı bir süreçtir. Ruhsal yeniden tanımlama ise boşanan kişinin kendi kimliğini oluşturarak sürecin başlarında oluşan olumsuz duygularla başa çıktığı bir süreci ifade etmektedir.

Kessler (1975) ilişkiye dair olumsuz düşüncelerin eşlik ettiği hayal kırıklı̆̆ (disillusionment), ilişki memnuniyetinin ve temasın belirgin bir biçimde azaldığı erozyon (erosion) aşamalarıyla başlayan ve kopuş (detachment), fiziksel ayrılık (physical separation), yas (mourning), ikinci ergenlik (second adolescence) ve sıkı çalışma (hard work) aşamalarıyla devam eden yedi basamaklı bir bakış açısı sunmaktadır. Erozyon aşamasından dönemeyen çiftler, devam eden süreçler içinde ilerlemekte ve ayrılığın getirdiği çok boyutlu kaybın yarattığı yasın ardından kendilerini yeniden keşfettikleri ve kimliklerini yeniden organize ettikleri aşamalardan geçmektedirler (aktaran Salts 1979).

Boşanmayı duygusal bir yaşam krizi olarak değerlendiren Wiseman (1975), beş aşamalı yas modelinden (bkz. KüblerRoss 1969) hareketle boşanma sonrası uyumu açıllamaya çalışmıştır. Bu süreçte boşanan bireyler inkar, kayıp ve depresyon, öfke ve duygu karmaşası (ambivalence), yaşam tarzı ve kimliğin yeniden düzenlenmesi ve kabul olmak üzere birbiriyle örtüşen beş aşamadan geçmektedir. Buna göre boşanmanın ayrılık kararının alınmasından başlayarak, yasal olarak harekete geçme ve boşanan çiftin birbirleri ve varsa çocukları arasındaki ilişkilerini, sosyal ve toplumsal alanlarını yeniden organize etmelerini içeren bir süreç yaşanmaktadır. Çiftin evliliklerinde yaşanan sorunları görmezden geldiği inkar aşamasını, ilişkide biriken stresin göz ardı edilemeyecek bir seviyeye gelerek artık sorunlarla başa 
çıkılamadığının fark edilmesi ve boşanmanın gündeme gelmesiyle tetiklenen bir kayıp süreci takip etmektedir. Bu aşamayla beraber pek çok duygu yoğun bir şekilde deneyimlenebilmektedir. Yaşam tarzı ve kimliğin yeniden düzenlenmesi süreci ile boşanan birey gelecek planlarına odaklanmaya başlamakta ve dikkatini, kimliğini eski eş ve evlilikten ayrışmaya yoğunlaştırmaktadır. $\mathrm{Bu}$ aşamalardan geçerek kişi, kendini yaşamının pek çok alanında yeterli hissetmeye başlamakta ve hem boşanmayla beraber değişen koşullarını hem de yakın ilişkilerini yeniden düzenlemektedir.

Froiland ve Hozman (1977), Wiseman (1975) ile benzer şekilde boşanma sürecini açıklamada beş aşamalı yas modelinden (bkz. Kübler-Ross 1969) faydalanmıştır. Buna göre, boşanma süreci evlilik ilişkisinde baş gösteren sorunların görmezden gelindiği ve yok sayıldığı inkar aşaması, hayal kırıklığıyla birlikte giden ve eşlerin yakın çevreden ittifak arayışında oldukları öfke aşaması, eşler arasında müzakere sürecinin başladığı ve ortak şartlar konusunda anlaşılmaya çalışıldığı pazarlık aşaması, ilişkinin kaybından doğan ve benlik değerinin sorgulandığı, üzüntü ve karamsarlık duygularının olduğu depresyon aşaması ve son olarak evliliğin kaybedilişiyle yüzleşildiği kabul aşamasından oluşmaktadır.

Levy ve Joffe (1977) bir evliliğin sonlanması durumunda her biri kendine özgü gereksinimler, endişeler ve kişinin gelişebilmesi için firsatlar taşıyan ayrlma (separation), bireyleşme (individuation) ve yeniden bağlanma (reconnection) olarak adlandırdıkları gelişimsel basamaklardan geçildiğini belirtmektedir. Ayrılma, birbirinden farklı pek çok duygunun deneyimlendiği ve kişide tepetaklak olan hayatıyla nasıl baş edeceğiyle ilgili düşüncelerin ortaya çıktığı aşamadır. Levy ve Joffe'ye göre (1977) yalnızca bu aşama, beş aşamalı yas sürecinin (Kübler-Ross 1969) tüm aşamalarını içinde barındırmaktadır. Boşanma sürecinin bu kısmında olan kişilerin, deneyimledikleri duyguların normal olduğunu anlamaya ihtiyaçları vardır. Bununla beraber, süreç boyunca kendilerini nelerin beklediği ile ilgili hazırlanmaları ve yalnız olmayı öğrenmeleri konusunda desteklenmeleri, kontrol algılarını destekleyici olacaktır. Bireyleşme, eskinin yerini yeni bir varoluşun aldığı, bireyin aşina olmadığı bir düzene geçiş yaptığı ve yeni bir kimlik inşa ettiği bir aşamadır. Yeniden bağlanma ise, başarılı bir bireyleşme ardından geçmişin geride kaldığı ve yeni yakın ilişkilerin kurulduğu, ihtiyaçların anlamlı ilişkilerle doyurulduğu bir aşamadır. İlişkiler, ilişkilerdeki normlar ve sosyal ağların hepsi kişi için yenidir.

Ahrons'a göre (1980) boşanma, aile sisteminde değişiklikler yaratan bir geçiş sürecidir ve bu süreç boşanma için yasal olarak harekete geçilmesinden çok önce, evlilik içinde başlamaktadır. Buradan hareketle bireysel biliş, ailenin üstbilişi, sistemik ayrılma, sistemik yeniden düzenleme ve aileyi yeniden tanımlama olmak üzere meydana geliş sırası değişebilen beş geçiş süreci tanımlanmıştır. İlk aşama, eşlerin sıkıntılı hissettiği ancak sorunun kaynağını evlilik ilişkisinde aramaktan kaçındıkları bir inkar dönemine işaret etmektedir ve çocuk yapma, ilişkiye yapılan yatırımı durdurma gibi çeşitli baş etme stratejileri kullanılır. İkinci aşamada sıkıntının kaynağının aile sistemi olduğu aile üyeleri tarafından fark edilmeye başlanır ve eşe yönelik çelişkili duygular görülür. Mevcut roller yok olmaya başlarken yeni roller henüz oluşmamıştır. Üçüncü aşama ortamların ayrıldığı, sınır belirsizliklerinin yaşandığı ve yakın çevreye ayrılığın açıklanarak yasal işlemlere başlandığı bir sürece denk gelir. Dördüncü aşamanın en belirgin özelliği sınır belirsizlikleri ortadan kalkarken oluşan netleşmenin stres verici olmasıdır. Bu aşamada, ebeveynlerin çocukla kuracağı ilişki biçimine dair düzenlemeler yapılmıştır. Son aşamada ailenin yeni kimliği tanımlanır ve yeni bir evlilik söz konusu olabilir.

Boşanma sürecini, duygusal olarak gelgitlerin olduğu bir baş etme süreci ile kavramsallaştıran Kressel (1980), bu süreci hem birey hem de çift perspektifinden ele almıştır. Birey açısından, evliliğin sona erme ihtimalinin yok sayıldığı inkâr, olumsuz duyguların eşlik ettiği ve sosyal etkileşimin azaltıldığı yas, eski eşe ve karşı cinse yöneltilen düşmanlık ve öfke ve içgörü kazanılıp ileriye dönük gerçekçi planların yapıldığı kademeli olarak gerçekleşen yeniden uyum olmak üzere dört baş etme aşaması tanımlanmıştır. Çift açısından ise bu baş etme süreci karar öncesi dönem, karar, müzakere (negotiating) ve yeniden dengeleme dönemi (re-equilibration) olmak üzere dört döneme ayrılmıştır. Karar öncesi dönem, evlilik ilişkisindeki hoşnutsuzluğun ve gerilimin fark edildiği, buna çeşitli çözüm yollarının arandığı, çözüme ulaşamamanın bir kırılma noktası yaratarak yasal danışmanlığa başvurulduğu bir süreci kapsamaktadır. Bu süreç, birkaç hafta sürebildiği gibi yıllarca da sürebilmektedir. İkinci dönem, duygusal ve bilişsel olarak gelgitler ile özetlenebilmektedir. Eşlerden en az birinin boşanma kararını aldığı ancak karar almanın başlangıçta verdiği rahatlamanın, yerini kaygı ve korkuya bıraktığı ve yeniden yakınlaşmaların görülebildiği bir süreçtir. En nihayetinde tekrar artan tartışmalar ve gerilim kendini gösterir. Yasal düzenlemeler konusunda kararların alındığı müzakere ve çatışmanın olduğu üçüncü döneme yoğun duygular eşlik etmektedir. Bu dönem, boşanma konusunda duygusal bir kararsızlı ve evlilik sırasında finansal sıkıntılar varsa daha zorlayıcı olabilmektedir. Son dönem ise gelgitli ilerleyen sürecin bir dengeye oturduğu ve baş etme süreci başarılı bir şekilde ilerlediyse hem biten ilişkiye hem de eski eşe yönelik değerlendirmelerin daha nesnel bir hal aldığı bir döneme işaret etmektedir.

Hackney ve Bernard (1990) boşanma sürecini açlklayan yaklaşımların bireysel adaptasyonun önemi konusunda eksik kaldığını vurgulayarak, sekiz aşamadan oluşan bir Çift Boşanma Uyum Modeli (Dyadic Divorce Adjustment Model) geliştirmişlerdir. Bu model, eşlerden birinin veya her ikisinin bir sorun olduğunun farkına vardığı ilk basamak ile başlamakta, çiftin bu soruna vereceği tepkiyle devam etmektedir. Verilen tepki ya evlilik ya da boşanma danışmanlığının gündeme gelmesine etki etmektedir. Üçüncü aşama olan fanteziye kaçma (escape to fantasy) adeta bir savunma mekanizması görevi görerek, sorunları çözmek yerine telafi edici davranışlara başvurulan ve bir süre sonra eşlerin birbirinden uzaklaşmasına ve fiziksel ayrıllğa neden olan bir aşamadır. Devam eden süreçte iliş̧kinin bitişini kabullenme aşaması gelir ve bu aşamada geçmişin kabulü ile geleceğe dönük planlamalar yapılır. Yasal olarak boşanma, çiftin ayrllğının resmiyet kazandlğı ve yasal düzenlemelerin yapıldığı aşamadır. 
Psişik boşanma aşaması ile içsel olarak bir kopuş kastedilmekte ve özerklik basamağ ile hayatın, rollerin ve sorumlulukların yeniden şekillendirildiği görülmektedir.

Aktarılan tüm bu modellerde, boşanma sonrası uyumun bir süreç yaklaşımı içerisinde ele alınarak boşanma sürecinden ayrıştırılmadığı ve farklı kavramlarla ifade edilse de bireyin çeşitli alanlarda yapacağı yeni düzenlemelere işaret ettiği görülmektedir. Bununla birlikte boşanma sonrası uyumu, stres modelleri (Hill 1958, McCubbin ve Patterson 1983, Patterson 1988) ve ailenin sağlamlığı (Patterson 2002, Walsh 2016) çerçevesinde ele alan modeller de bulunmaktadır.

Hill'in (1958) geliştirmiş olduğu ABCX Aile Stres ve Baş Etme Modeli'ne göre bir aileyi krize yatkın hale getiren ve birbiriyle etkileşim halinde olan bazı faktörler vardır. Yaşanan olay (A), ailenin krizi karşılamak için kullanabileceği kaynaklar (B) ile etkileşime girer ve bu kaynaklar da ailenin söz konusu olaya yönelik tanımlarını (C) etkileyerek kriz (X) doğurur. Bu modele göre, bir aileyi krize karşı daha savunmasız hale getiren şey stres yaratan durumu karşılayacak kaynaklarının yetersizliği ve duruma yönelik olumsuz değerlendirmeleridir. McCubbin ve Patterson (1983) bu modeli genişleterek Çift ABCX Modelini ileri sürmüşlerdir. Genişletilmiş bu model, orijinal modele kriz sonrası faktörlerin eklenmesiyle oluşmuştur. "aA bileşeni" olayın yanı sıra aynı zamanda o olayın beraberinde gelen bir dizi stresöre, "bB bileşeni" ailenin var olan ve geliştirdiği kaynaklarına, "cC bileşeni" ailenin kriz yaratan deneyimi nasıl algıladığı ve anlamlandırdığına karşılık gelmektedir. "xX bileşeni" ise ailenin krize ve stresörlere yönelik tepkisinin bir sonucudur ve uyuma veya uyum bozukluğuna işaret etmektedir. $\mathrm{Bu}$ aile stres ve baş etme modeli, farklı stresli yaşam olaylarında ailenin uyumunu değerlendirmek amacıyla sıklıkla kullanılsa da boşanma konusunu bu model çerçevesinde ele alan sınırlı sayıda çalışma bulunmaktadır. Bu çalışmalar, boşanma sonrası uyumu $\mathrm{xX}$ bileșenine yerleștirerek boşanan kişinin uyum düzeyini etkileyen çeşitli değişkenleri değerlendirmektedir (bkz. Plummer ve Koch-Hattem 1986, Tschann ve ark.1989, Nikparvar ve ark. 2021).

Aile Alı̧ma ve Uyum Tepkisi (Family Adjustment and Adaptation Response, FAAR) (Patterson 1988) modeline göre, ailenin kriz yaşantısı sonucunda deneyimleyeceği alışma ve uyum talepler (demands), yetenekler (capabilities) ve anlamlarn (meanings) karşılıklı etkileşimiyle ortaya çıkmaktadır. Talepler stresörler, eşlik eden güçlükler ve günlük mücadelelerden; yetenekler ailenin baş etmek için sahip olduğu kaynaklar ve davranışlardan oluşmaktadır. Anlamlar ise ailenin talepler ve yeteneklerini, aile olarak kendisini nasıl tanımladığını ve ailenin hayata bakışını ifade etmektedir. Ailenin yeteneklerini aşan talepler söz konusu olduğunda oluşan dengesizlik kısa sürede çözülemezse, ailenin işleyişinde bozulmalar meydana gelir. Eğer aile bu süreci işlevselliğine olumlu bir şekilde yansıtmayı becerirse, o zaman ailenin sağlamlığı söz konusu olabilir. Patterson (1988) boşanmayı aile sistemini parçalayan ve istikrarı bozan bir aile krizi olarak görmekte ve eskinin yıkılarak yeninin kurulmasını zorunlu kılan bir uyum aşamasının altını çizmektedir.
Ailenin sağlamlığı (family resilience), olumsuz yaşam olaylarıyla mücadelede bireysel sağlamlık gibi, bir "birim" halinde ailenin sağlamlığının da söz konusu olabileceği düşüncesinden kaynağını almaktadır (Patterson 2002). Aile Alışma ve Uyum Tepkisi Modeli ile aile sağlamlığı görüşünü bir araya getiren Patterson'a (2002) göre, modelin olumlu bir sonuç olarak konumlandırdığı ailenin uyumu, burada ailenin sağlamlığına karşıllı gelmektedir. Ailenin sağlamlığından söz edebilmek için ailenin en az iki üyesini ilgilendiren bir durum olması gerekmektedir. FAAR modelinde aile üyeleri ile aile ve aile ile toplum arasındaki ilişkiye yapılan vurgu ailenin sağlamlığı açısından önemlidir. Başka bir deyişle, aile birey ve toplumu birbirine bağlayan bir araçtır ve bu bağlantı hem bireyin hem de ailenin gerek sosyalizasyon sürecine katkıda bulunarak gerekse çeşitli açılardan koruyuculuk sağlayarak sağlamlığı teşvik eder. Öncesi ve sonrasıyla uzun bir sürece yayılan yapısı ve yasal konularla beraber hayatın yeniden düzenlenmesi gibi karmaşık bir dizi değişiklik içeren boşanma durumunda sağlamlığa ulaşmak da bir süreç içinde gelişir (Walsh 2016).

Walsh (2016) boşanmayı bir ailenin karşılaşabileceği olumsuz yaşam geçişlerinden biri olarak değerlendirmekte ve bu yaşam krizlerine uyumu psikolojik sağlamlık açısından ele almaktadır. Buradan hareketle "paylaşılan inanç sistemleri" (shared belief systems), "organizasyonel süreçler" (organizational processes) ve iletişim/sorun çözme süreçleri (communication/problem-solving processes) olmak üzere üç ana koldan ve her bir kolun kendine ait üçer sürecinden oluşan Aile Sağlamlık Teorisi'ni (Family Resilience Theory) ortaya koymuştur. Aile sağlamlığını, olumsuz bir yaşam deneyimiyle baş etmenin ötesinde ailenin değişim ve dönüşümünü de kapsayan adaptasyon kapasitesi olarak tanımlamaktadır. Bu adaptasyona ulaşmak, ailenin söz konusu olumsuz deneyimi ele alış biçimiyle doğrudan ilgilidir. Ailenin etkin bir biçimde hem üyelerini hem de ilişkilerini ve yatırımlarını yeniden düzenleyerek uyuma ulaşması beklenmektedir (Walsh 2016). Walsh'a (2016) göre, boşanma birbirini izleyen yıkıcı geçişlerden oluşan bir süreçtir ve süreç içinde değişen gereksinimler giderilerek uyuma ulaşılabilir.

Görüldüğü üzere boşanma sürecini anlamaya yönelik çok sayıda yaklaşım bulunmaktadır. Bu yaşam geçişinin her bir noktası farklı güçlüklere neden olabilmekte, birtakım gereklilikler ve hedeflerin yerine getirilmesine işaret etmektedir. Sürecin kendisinden ziyade sürecin getirdiği temel gereklilikler ve sorunların iyi tanımlanması durumunda, uygulanacak müdahale programlarının uygun psikoterapi hedef ve tekniklerinden oluşabileceği ve ancak böylelikle boşanma sonrası uyumu destekleyici olabileceği düşünülmektedir. Örneğin, yaşananlara anlam verme, mevcut kaynaklar kullanılırken yeni kaynaklar geliştirebilme, boşanmanın yarattığı yas ve üzüntünün işlemlenmesi başarılı bir geçiş süreci için etkili hedeflerden bazılarıdır (Huff ve ark 2020).

\section{Boşanma Sonrası Uyumun Değerlendirilmesi}

Uyumun çok boyutlu doğası nasıl ölçüleceği konusunu önemli hale getirmektedir. Uyumun nasıl tanımlandığı doğal olarak 
nasıl ölçüleceğini de belirlemektedir. Genel olarak iyi oluş ve psikolojik iyilik hali ekseninde uyumu değerlendiren araştırmacıların buna uygun ölçme yollarına başvurdukları ve uyumu boşanmaya özgü özellikleri dışarda bırakarak ele aldıkları görülmektedir (örneğin, Berman 1988, Doherty ve ark. 1989, Lorenz ve ark. 1997, Kramrei ve ark. 2007, Bowen ve Jensen 2017). Bazı araştırmalar ise uyumu, boşanmaya ve eski ilişkiye ait bazı özellikler çerçevesinde değerlendirmektedir. Örneğin, Wang ve Amato (2000) yapmış oldukları çalışmada boşanma sonrası uyumu boşanma kararını kimin aldığı gibi boşanmaya ilişkin belli sorular ve eski eşe bağlanma düzeyi çerçevesinde değerlendirmişlerdir.

Boşanmanın çok bileşenli yapısı, boşanma sonrası uyumun daha kapsamlı ve bu deneyime özgü bir çerçevede değerlendirilmesi gerekliliğini doğurmuştur. Bu doğrultuda, uyumu boşanmış bireylere özgü geliştirilen araçlar vasıtasıyla ölçen araştırmaların sayısı artmaya başlamıştır (Plummer ve Koch-Hattem 1986, Sweeper ve Halford 2006, Vukalovich ve Caltabiano 2008). Sweeper ve Halford (2006) ayrılık sonrası yakın ilişkinin kaybıyla duygusal bağlllı̆ın zedelenmesinin, sosyal bağların zayıflamasından kaynaklanan yalnızlık duygusunun ve ebeveynliğin eski eşle birlikte yeniden düzenlenmesi gereğinin uyum ile ilişkili konular olmasından hareketle, Ayrilığa Psikolojik Uyum Ölçeği'ni (The Psychological Adjustment to Separation Test) geliştirmişlerdir. Söz konusu ölçek 8 maddeden oluşan "eski partnere duygusal bağllık (former partner attachment)", 11 maddeden olușan "yalnızlık (lonely negativity)" ve 7 maddeden olușan "ortak ebeveynlik çatışması (coparenting conflict)" olmak üzere üç ayrı eksende uyumu değerlendiren 26 maddeden oluşmaktadır. Ölçek hem boşanmaya hem de romantik ilişki bitimine uyumun değerlendirilmesinde kullanılmaktadır.

Daha kapsamlı bir şekilde boşanmaya/ayrılığa uyumu değerlendirmesiyle öne çıkan Fisher Boşanmaya/Ayrıı̆ı̆a Uyum Ölçeği ilgili alanyazında sıklıkla kullanılmaktadır. Fisher $(1976,1978)$ tarafından geliştirilen özgün ölçek 100 maddeden oluşmakta ve altı boyutta uyum düzeyini değerlendirmektedir. Bu boyutlar: (1) bireyin benliğiyle ilgili değerlendirmelerinden oluşan "kendilik değeri", (2) eski eş ve ilişkiyle ilgili duygu ve düşünceleri değerlendiren "ilişkiden ayrışma", (3) eski eşe yönelik öfkeyi ve öfkenin deneyimlenme biçimini değerlendiren "öfke", (4) ilişkinin kaybına dair tepkileri değerlendiren "yas tepkisi", (5) kişinin olası bir yeni ilişkiye yönelik yaklaşımını değerlendiren "güven ve yakınlık" ve (6) ayrılığın sosyal çevrede paylaşılması ve bireyin kendini sosyal olarak yeniden konumlandırmasin değerlendiren "sosyal kendilik değeri"dir (Fisher 1978). Çeşitli kültürlere uyarlanmış olan ölçeğin Türkçe formu "sosyal kendilik değeri" haricindeki beş faktör için iyi düzeyde psikometrik özelliklere sahiptir (Yilmaz ve Fişiloğlu 2006). Yllmaz ve ark. (2021) hem uygulama kolaylığı yaratmak hem de araştırmalarda daha kullanışlı olmasını sağlamak amacıyla ölçeğin 25 maddeden oluşan kısa formunu oluşturmuş ve psikometrik özelliklerinin uzun form ile benzer olduğunu göstermişlerdir.

\section{Tartışma}

Evlilik yaşamının sona ermesi anlamına gelen boşanma, değişen sosyal, ekonomikvekültürel gelişmelerin bir sonucu olarak günden güne daha sık karşılaşılan bir deneyim haline gelmiştir. Pek çok ülkede çarpııı bir şekilde artan boşanma oranları ve boşanmanın bireyin hayatına çok yönlü etkileri bu yaşam deneyiminin daha iyi anlaşılması gerekliliğini ortaya koymaktadır.

Boşanma, kendine has özellikleri olan çok boyutlu bir yaşam krizidir. Boşanma kararının kesinleşmesi ile gündeme gelen velayet, nafaka, tazminat, malbölüşümü gibi yasal düzenlemelerde yaşanan anlaşmazlıklar, boşanan bireyin yaşam kalitesini ve boşanma sonrası uyumunu olumsuz yönde etkileyebilmektedir (Güler 2017, Demirbaş 2018). Benzer şekilde boşanmayla beraber ekonomik sorunlar ve yaşam standartlarında önemli değişimler meydana gelmektedir (Asanjarani ve ark. 2017). Bununla birlikte hem ortak arkadaşlar hem de eski eşin ailesiyle kurulmuş olan ilişkilerde zayıflamalar, boşanmış bireylerin sosyal ağlarında ve etkileşimlerinde daralmalara yol açmaktadır (Kramrei ve ark. 2007). Ayrıca, boşanan bireylere yönelik toplumsal önyargılar, boşanma oranlarındaki artışa rağmen varlığını sürdürmekte ve doğası gereği zorlu olan bu deneyimi daha da güç hale getirebilmektedir (Herman 1974, Arıkan 1996).

Holmes ve Rahe (1967) boşanmanın, eşin ölüm yoluyla kaybına oldukça benzer bir stres kaynağı olduğunu belirtmektedir. Bununla paralel olarak, gözden geçirilen araştırmalar evliliğin sonlanmasının hem psikolojik (Menaghan ve Lieberman 1986, Emery ve Wyer 1987, Doherty ve ark. 1989, Gove ve Shin 1989, Lillard ve Waite 1995, Lorenz ve ark. 1997, Hope ve ark. 1999, Amato 2000, Thuen 2000, Forste ve Heaton 2004, Afifi ve ark. 2006) hem de fizyolojik (Zick ve Smith 1991, Lillard ve Waite 1995, Hemstrom 1996, Rogers 1996, Joung ve ark. 1997, Murphy ve ark. 1997, Sbarra ve ark. 2011) olarak boşanan kişileri olumsuz biçimde etkileyebildiğini ortaya koymaktadır.

Evlilik ilişkisinin sonlanmasının bireyin hayatı üzerinde yarattığı bu çok boyutlu olumsuz etkilere rağmen boşanma oranlarının artmaya devam ediyor olması, boşanma sonrası uyum sürecinin önemini arttırmaktadır. Bu noktada, hem uyumu tanımlama ve değerlendirmeye hem de boşanma sonrası uyum sürecini açıklamaya yönelik yaklaşımların ayrıştığı ve ortaklaştı̆̆ı noktalar dikkat çekmektedir. Boşanma sonrası uyumun farklı şekillerde tanımlandığı ve uyumun tanımlanış biçiminin nasıl ölçüleceğini etkilediği görülmektedir. Boşanma sonrası uyumu psikolojik belirtilerin varlı̆gı ya da yokluğu ve iyi oluş üzerinden açlklayan araştırmacıların uyumu değerlendirmek için depresyon, anksiyete, yaşam kalitesi gibi göstergeleri dikkate aldıkları görülmektedir (Berman 1988, Doherty ve ark. 1989, Lorenz ve ark. 1997, Kramrei ve ark. 2007, Bowen ve Jensen 2017). Fakat, boşanma sonrası uyumun bunların ötesinde ve boşanmaya has özellikler taşıyan bir kavrama karşılık geldiği açıktır. Boşanma sonrası uyumun, genel uyum göstergelerinden ayrı bir kavrama karşılık geldiğinin kabul edilmesiyle birlikte, boşanmaya/ayrillğa özgü bir perspektif kullanılarak ölçülmesinin (Fisher 1976, 1978, 
Sweeper ve Halford 2006, Yilmaz ve Fişiloğlu 2006, Yılmaz ve ark. 2021), uyumun hem güvenilir hem de geçerli bir biçimde değerlendirilmesini sağladığı düşünülmektedir.

Boşanmayı ve boşanma sonrası uyumu anlamaya yönelik yaklaşımların süreç (Bohannan 1970, Kessler 1975, Wiseman 1975, Froiland ve Hozman 1977, Levy ve Joffe 1977, Pais ve White 1979, Ahrons 1980, Kressel 1980, Hackney ve Bernard 1990) ile stres ve sağlamlık (Hill 1949, McCubbin ve Patterson 1983, Patterson 1988, Patterson 2002, Walsh 2016) bakış açısı olmak üzere iki ana hat üzerinden ilerlediği görülmektedir. Süreç yaklaşımları,boşananbireyin sırasıveyoğunluğu değişebilençeşitli aşamalardan geçtiğini ve boşanma sonrası uyumun bu sürecin bir parçası olduğunu ileri sürmektedir. Stres ve aile sağlamllğı modelleri ise, ailenin karşılaştığı yaşam krizine göstereceği uyum süreçlerine odaklanmaktadır. Bu modellerin, aileyi krize, uyuma veya sağlamlığa yatkın hale getiren ve birbiriyle etkileşim halinde olan bazı faktörlere odaklandığı dikkat çekmektedir. Boşanma deneyiminin bu şekilde ele alınması, boşanma sürecine giren kişinin içinden geçeceği aşamaların neler getirebileceğinin bilinmesini sağlayarak başa çıkmayı kolaylaştıracaktır (Korkut 2012). Dahası, boşanan bireyin içinde bulunduğu aşamayı doğru bir şekilde belirleyen ve bireyin içinde bulunduğu aşamada karşılaştığ1 güçlükleri etkin bir şekilde hedefleyen psikoterapi müdahalelerinin geliştirilip uygulanması açısından da faydalı olacaktır. Ayrıca, boşanma sürecinin erken aşamalarında çiftin durumuna özgü oluşturulacak kavramsallaştırma, uygulanacak terapötik müdahaleyi şekillendirerek bu inişli çlkışlı sürecin en az zararla ilerlemesini sağlayacak, hatta çiftin ayrılık kararını yeniden gözden geçirmesini teşvik edici olacaktır (Pearce Plauche ve ark. 2016).

\section{Sonuç}

Sonuç olarak boşanma sürecinin, kişilerin hayatında karışıklık yaratan veçeşitli alanlarda bireyin yeniden düzenleme gerekliliğini doğuran psikolojik olarak zorlayıcı bir yaşam deneyimi olduğu açıktır. Bu süreçte, boşanan bireyin alacağı doğru bilgi ve etkili bir psikolojik desteğin kritik olduğu düşünülmektedir. Bu makalede gözden geçirilen çalışmalar, boşanmış bireylerin iyilik halini gözeten psikolojik yaklaşımlara fikir oluşturması bakımından hem teori hem de psikoterapi alanında fikir verici olacaktır.

Yazarların Katkıları: Yazarlar çalışmaya önemli bir bilimsel katkı sağladıklarını ve makalenin hazırlanmasında veya gözden geçirilmesinde yardımcı olduğunu kabul etmiştir.

Danışman Değerlendirmesi: Dış bağımsız.

Çıkar Çatışması: Yazarlar çıkar çatışması bildirmemiştir.

Finansal Destek: Yazarlar bu çalışma için finansal destek almadığını beyan etmiştir.

Authors Contributions: The authors attest that she has made an important scientific contribution to the study and has assisted with the drafting or revising of the manuscript.

Peer-review: Externally peer-reviewed.

Conflict of Interest: No conflict of interest was declared by the authors. Financial Disclosure: The authors declared that this study has received no financial support.

\section{Kaynaklar}

Afifi TO, Cox BJ, Enns MW (2006) Mental health profiles among married, never-married, and separated/divorced mothers in a nationally representative sample. Soc Psychiatry Psychiatr Epidemiol, 41:122-129.

Ahrons CR (1980) Divorce: A crisis of family transition and change. Fam Relat, 29:533-540.

Alpaslan AHN (2018) Reframing the death of the marital relationship as an opportunity for growth: a programme for facilitating post-divorce adjustment. Soc Work, 54:308-326.

Amato PR (2000) The consequences of divorce for adults and children. J Marriage Fam, 62:1269-1287.

Amato PR, Keith B (1991) Parental divorce and adult well-being: A metaanalysis. J Marriage Fam, 53:43-58.

Arıkan Ç (1996) Halkın Boşanmaya İlişkin Tutumları Araştırması. Ankara, Başbakanlık Aile Araştırma Kurumu.

Asanjarani F, Jazayeri RS, Fatehizade M, Etemadi O, Demol J (2017) Exploring factors affecting post-divorce adjustment in Iranian women: A qualitative study. Social Determinants of Health, 3:15-25.

Baum N (2007) "Separation guilt" in women who initiate divorce. Clin Soc Work J, 35:47-55.

Berman WH (1988) The role of attachment in the post-divorce experience. J Pers Soc Psychol, 54:496-503.

Bevvino DL, Sharkin BS (2003) Divorce adjustment as a function of finding meaning and gender differences. J Divorce Remarriage, 39:81-97.

United Nations (2020) 2019 Demographic Yearbook, 70th issue. New York, United Nations.

Bloom BL, Hodges WF, Kern MB, McFaddin SC (1985) A preventive intervention program for the newly separated: Final evaluations. Am J Orthopsychiatry, 55:9-26.

Boon C (2005) Women after divorce: exploring the psychology of resilience (Doctoral dissertation). Pretoria, University of South Africa.

Booth A, Amato P (1991) Divorce and psychological stress. J Health Soc Behav, 32:396-407.

Bowen GL, Jensen TM (2017) Late-life divorce and postdivorce adult subjective well-being. J Fam Issues, 38:1363-1388.

Bozdağ CI (2019) Türk hukukunda boşanma sebepleri ve kusurun etkisi (Yüksek lisans tezi). Konya, KTO Karatay Üniversitesi.

Can Y, Aksu NB (2016) Boşanma sürecinde ve sonrasında kadın. Elektronik Sosyal Bilimler Dergisi, 15:888-902.

Canbulat N (2017) Boşanmış kadınlarla yürütülen duygu odaklı grupla psikolojik danışmanın etkililiğinin incelenmesi (Doktora tezi). İzmir, Ege Üniversitesi.

Canham SL, Mahmood A, Stott S, Sixsmith J, O'Rourke N (2014) 'Til divorce do us part: Marriage dissolution in later life. J Divorce Remarriage, 55:591612.

Chiriboga DA (1982) Adaptation to marital separation in later and earlier life. J Gerontol, 37:109-114.

Colburn Jr K, Lan Lin P, Moore MC (1992) Gender and the divorce experience. J Divorce Remarriage, 17:87-108.

Cohen O, Dekel R (2000) Sense of coherence, ways of coping, and well being of married and divorced mothers. Contemp Fam Ther, 22:467-486.

Cooney TM, Uhlenberg P (1990) The role of divorce in men's relations with their adult children after mid-life. J Marriage Fam, 52:677-688.

Demirbaş A (2018) Güncel tartışmalarla yoksulluk nafakası. İstanbul Medipol Üniversitesi Hukuk Fakültesi Dergisi, 5:219-235. 
Diedrick P (1991) Gender differences in divorce adjustment. J Divorce Remarriage, 14:33-46.

Doherty WJ, Su S, Needle R (1989) Marital disruption and psychological well-being: A panel study. J Fam Issues, 10:72-85.

OECD (2019) Family database. http://www.oecd.org/els/family/database. htm (Accessed 14.2.2020).

Emery R (1994) Renegotiating Family Relationships: Divorce, Child Custody, and Mediation, 2nd ed. New York, Guilford Press.

Emery RE, Wyer MM (1987) Child custody mediation and litigation: An experimental evaluation of the experience of parents. J Consult Clin Psychol, 55:179-186.

Fisher BF (1976) Identifying and meeting needs of formerly-married people through a divorce adjustment seminar (Doctoral dissertation). Greeley, University of Northern Colorado.

Fisher BF (1978) Rebuilding: When Your Relationship Ends. Canada, Impact Publishers.

Fogas BS, Wolchik SA, Braver SL, Freedom DS, Bay R C (1992) Locus of control as a mediator of negative divorce冈related events and adjustment problems in children. Am J Orthopsychiatry, 62:589-598.

Forste R, Heaton TB (2004) The divorce generation: Well-being, family attitudes, and socioeconomic consequences of marital disruption. J Divorce Remarriage, 41:95-114.

Frisby BN, Booth-Butterfield M, Dillow MR, Martin MM, Weber KD (2012) Face and resilience in divorce: The impact on emotions, stress, and postdivorce relationships. J Soc- Pers Relatsh, 29:715-735.

Froiland DJ, Hozman TL (1977) Counseling for constructive divorce. Pers Guid J, 55:525-529.

Gove WR, Shin HC (1989) The psychological well-being of divorced and widowed men and women: An empirical analysis. J Fam Issues, 10:122-144.

Güler G (2017) Ebeveyn yabancılaştırma sendromu ve boşanma. Türkiye Klinikleri J Child Psychiatry-Special Topics, 3:225-228.

Hackney H, Bernard JM (1990) Dyadic adjustment processes in divorce counseling. J Couns Dev, 69:134-143.

Hemström Ö (1996) Is marriage dissolution linked to differences in mortality risks for men and women? J Marriage Fam, 58:366-378.

Hensley R (1996) Relationship termination and the Fisher Divorce Adjustment Scale: A comparative study. J Divorce Remarriage, 25:139-150.

Herman SJ (1974) Divorce: a grief process. Perspect Psychiatr Care, 3:108-112.

Hill R (1958) 1. Generic features of families under stress. Soc Casework, 39:139-150

Holmes TH, Rahe RH (1967) The social readjustment rating scale. J Psychosom Res, 11:213-218.

Hope S, Power C, Rodgers B (1999) Does financial hardship account for elevated psychological distress in lone mothers? Soc Sci Med, 29:381-389.

Huff SC, Markham MS, Larkin NR, Bauer ER (2020) Therapy for divorcing couples: Managing the transition out of the Relationship. In The Handbook of Systemic Family Therapy: Volume 3, (Eds KS Wampler, AJ Blow):295-316. New York, Wiley.

Joung IM, Stronks K, Van de Mheen H, van Poppel FW, Van der Meer JBW, Mackenbach JP (1997) The contribution of intermediary factors to marital status differences in self-reported health. J Marriage Fam, 59:476-490.

Kalmijn M, Monden CW (2006) Are the negative effects of divorce on well] being dependent on marital quality? J Marriage Fam, 68:1197-1213.

Karadeniz Özbek S (2019) Boşanma sonrası psikolojik destek programının bireylerin uyum düzeylerine etkisi (Doktora tezi). Samsun, Ondokuz Mayıs Üniversitesi.
Kiremitçi M (2014) Boşanma sürecinde müşterek velayet ve toplumsal bakış açısı (Doktora tezi). İstanbul, İstanbul Üniversitesi.

Kitson GC, Holmes WM (1992) Portrait of Divorce: Adjustment to Marital Breakdown. New YorkGuilford Press.

Kitson GC, Morgan LA (1990) The multiple consequences of divorce: A decade review. J Marriage Fam, 52:913-924.

Kitson GC, Raschke HJ (1981) Divorce research: What we know; what we need to know. J Divorce, 4:1-37.

Kołodziej-Zaleska A, Przybyła-Basista (2016) Psychological well-being of individuals after divorce: The role of social support. Current Issues on Personality Psychology, 4:206-216.

Korkut Y (2012) Bir geçiş krizi olarak boşanma. Psikoloji Çalışmaları, 23:99112

Kramrei E, Coit C, Martin S, Fogo W, Mahoney A (2007) Post-divorce adjustment and social relationships: A meta-analytic review. J Divorce Remarriage, 46:145-166.

Kressel K (1980) Patterns of coping in divorce and some implications for clinical practice. Fam Relat, 29:234-240.

Kulik L, Heine-Cohen (2011) Coping resources, perceived stress and adjustment to divorce among Israeli women: Assessing effects. J Soc Psychol 151:5-30.

Kübler-Ross E (1969) On Death and Dying. New York, Macmillan

Levy TM, Joffe W (1978) Counseling couples through separation: A developmental approach. Fam Ther, 5:267-276.

Lillard LA, Waite LJ (1995) 'Til death do us part: Marital disruption and mortality. Am J Sociol, 100:1131-1156.

Lorenz FO, Simons RL, Conger RD, Elder Jr GH, Johnson C, Chao W (1997) Married and recently divorced mothers' stressful events and distress: Tracing change across time. J Marriage Fam, 59:219-232.

Madden-Derdich DA, Leonard SA, Christopher FS (1999) Boundary ambiguity and coparental conflict after divorce: An empirical test of a family systems model of the divorce process. J Marriage Fam, 61:588-598.

Mastekaasa A (1997) Marital dissolution as a stressor: Some evidence on psychological, physical, and behavioral changes in the pre-separation period. J Divorce Remarriage, 26:155-183.

McCubbin H, Patterson J (1983) The family stress process: The double ABCX model of family adjustment and adaptation. Marriage Fam Rev, 6:7-37.

Memişoğlu Bozan AG (2019) Boşanma davalarında nafakalar (Doktora tezi). İstanbul, İstanbul Kültür Üniversitesi.

Menaghan EG, Lieberman MA (1986) Changes in depression following divorce: A panel study. J Marriage Fam, 48:319-328.

Muñoz-Eguileta A (2007) Irrational beliefs as predictors of emotional adjustment after divorce. J Ration Emot Cogn Behav Ther, 25:1-15.

Murphy M, Glaser K, Grundy E (1997) Marital status and long-term illness in Great Britain. J Marriage Fam, 59:156-164.

Nikparvar F, Stith S, Dehghani, M, Liang JG (2021) The process of adjusting to divorce after leaving violent marriages: a case study of Iranian women. J Interpers Violence, 36:4468-4494.

Öngider N (2013) Boşanmanın çocuk üzerindeki etkileri. Psikiyatride Güncel Yaklaşımlar, 5:140-161.

Özcan Çelik B (2015) Genel boşanma sebebi olarak evlilik birliğinin temelinden sarsılması (Yüksek lisans tezi). Ankara, Ankara Üniversitesi.

Pais J, White P (1979) Family Redefinition: A review of the literature toward a model of divorce adjustment. Journal of Divorce, 2:271-281.

Patterson JM (1988) Families experiencing stress: I. The Family Adjustment and Adaptation Response Model: II. Applying the FAAR Model to healthrelated issues for intervention and research. Fam Syst Med, 6:202-237. 
Patterson JM (2002) Integrating family resilience and family stress theory. J Marriage Fam, 64:349-360.

Pearce Plauche H, Marks LD, Hawkins AJ (2016) Why we chose to stay together: Qualitative interviews with separated couples who chose to reconcile. J Divorce Remarriage, 57:317-337.

Peters A, Liefbroer AC (1997) Beyond marital status: Partner history and well-being in old age. J Marriage Fam, 59:687-699.

Pietsch UK (2002) Facilitating post-divorce transition using narrative therapy. J Couple Relatsh Ther, 1:65-81.

Pledge DS (1992) Marital separation/divorce: A review of individual responses to a major life stressor. J Divorce Remarriage, 17:151-182.

Plummer LP, Koch-Hattem A (1986) Family stress and adjustment to divorce. Fam Relat, 35:523-529.

Raley RK, Sweeney MM (2020) Divorce, repartnering, and stepfamilies: A decade in review. J Marriage Fam, 82:81-99.

Rogers RG (1996) The effects of family composition, health, and social support linkages on mortality. J Health Soc Behav, 37:326-338.

Rohde-Brown J, Rudestam KE (2011) The role of forgiveness in divorce adjustment and the impact of affect. J Divorce Remarriage, 52:109-124.

Sakraida TJ (2008) Stress and coping of midlife women in divorce transition. West J Nurs Res, 30:869-887.

Salts CJ (1979) Divorce process: Integration of theory. J Divorce, 2:233-240.

Sayan Karahan A, Yıldırım İ (2021) Aile mahkemelerinde boşanan bireylerin boşanma sonrası yaşama uyumlarına ilişkin bir inceleme. Türkiye Adalet Akademisi Dergisi, 46:55-74.

Sbarra DA, Law RW, Portley RM (2011) Divorce and death: A meta-analysis and research agenda for clinical, social, and health psychology. Perspect Psychol Sci, 6:454-474.

Smith Barnet H (1990) Divorce stress and adjustment model: Locus of control and demographic predictors. J Divorce, 13:93-110.

Sonat KA (2013) Ana babanın eğitimi devam eden ergin çocuğa karşı nafaka yükümlülüğü. Marmara Üniversitesi Hukuk Fakültesi Hukuk Araştırmaları Dergisi, 19:235-292.

Symoens S, Colman E, Bracke P (2014) Divorce, conflict, and mental health: How the quality of intimate relationships is linked to postखdivorce well $\mathbb{}$ being. J Appl Soc Psychol, 44:220-233.

Sweeper S, Halford K (2006) Assessing adult adjustment to relationship separation: The Psychological Adjustment to Separation Test (PAST). J Fam Psychol, 20:632-640.

Şanlı Yalın Ş (2017) Türk hukukunda anlaşmalı boşanma (Yüksek lisans tezi). İstanbul, İstanbul Aydın Üniversitesi.

Şen B (2013) Boşanma süreci ve arabuluculuğu (Doktora tezi). Ankara, Hacettepe Üniversitesi.

Şener A, Terzioğlu G (2008) Bazı sosyo-ekonomik ve demografik değişkenler ile iletişimin eşler arası uyuma etkisinin araştırılması. Sosyal Politika Çalışmaları Dergisi, 13:7-20.

Thomas C, Ryan M (2008) Women's perception of the divorce experience: A qualitative study. J Divorce Remarriage, 49:210-224.
Thuen F (2001) Psychiatric symptoms and perceived need for psychiatric care after divorce. J Divorce Remarriage, 34:61-76.

TÜİK (2012) İstatistik göstergeler 1923-2013. Ankara, Türkiye İstatistik Kurumu.

TÜİK (2019) Evlenme ve boşanma istatistikleri. https://tuikweb.tuik.gov.tr/ PreHaberBultenleri.do?id=33708 (Accessed 23.3.2020).

TÜİK (2020) Evlenme ve boşanma istatistikleri. https://tuikweb.tuik.gov.tr/ PreHaberBultenleri.do?id=37211. (Accessed 03.04.2021).

Trovato F (1986) The relationship between marital dissolution and suicide: The Canadian case. J Marriage Fam, 48:341-348.

Tschann JM, Johnston JR, Wallerstein JS (1989) Resources, stressors, and attachment as predictors of adult adjustment after divorce: A longitudinal study. J Marriage Fam, 51:1033-1046.

Uhlenberg P, Myers MAP (1981) Divorce and the elderly. Gerontologist, 21:276-282.

Veevers JE (1991) Traumas versus strens: a paradigm of positive versus negative divorce outcomes. J Divorce Remarriage, 15: 99-126.

Vukalovich D, Caltabiano N (2008) The effectiveness of a community group intervention program on adjustment to separation and divorce. J Divorce Remarriage, 48:145-168.

Wallerstein JS (1986) Women after divorce: Preliminary report from a tenyear follow-up. Am J Orthopsychiatry, 56:65-77.

Walsh F (2016) Applying a family resilience framework in training, practice, and research: Mastering the art of the possible. Fam Process, 55:616-632.

Wang H, Amato PR (2000) Predictors of divorce adjustment: Stressors, resources, and definitions. J Marriage Fam, 62:655-668.

Wilder SE (2016) Predicting adjustment to divorce from social support and relational quality in multiple relationships. J Divorce Remarriage, 57:553572.

Wiseman RS (1975) Crisis theory and the process of divorce. Soc Casework, $56: 205-212$

Yárnoz-Yaben S (2017) Grief due to divorce: relationship with attachment style and effects on subjective well-being and co-parenting. Estud Psicol, 38:667-688

Yárnoz S, Plazaola M, Etxeberria J (2008) Adaptation to divorce: an attachment-based intervention with long-term divorced parents. J Divorce Marriage, 49:291-307.

Yilmaz AE, Fişiloğlu H (2006) Psychometric properties of the Fisher Divorce Adjustment Scale in a Turkish divorced sample. J Divorce Remarriage, $4: 149-169$.

Yılmaz AE, Akyüz Z, Bintaş Zörer P, Erarslan İngeç Ö, Öksüzler Cabılar B, Tulum Akbulut S (2021) Derivation and psychometric evaluation of the Fisher Divorce Adjustment Scale-Short Form in a Turkish sample. J Divorce Remarriage, 62:41-65.

Zick CD, Smith KR (1991) Marital transitions, poverty, and gender differences in mortality. J Marriage Fam, 53:327-336. 